\title{
Privatization Policy and Rural Development: An Assessment of Power Holding Company of Nigeria in Ijumu Local Government of Kogi State
}

\author{
${ }^{1}$ Raji Abdulwasiu Adeyemi, ${ }^{2}$ Mohd.Haniff Jedin ${ }^{3}$ Muhammed Subhan \& \\ ${ }^{4}$ Nurhaizal Azam Arif \\ ${ }^{1-3}$ School of International Studies, Universiti Utara Malaysia, Malaysia \\ ${ }^{4}$ Faculty of International Studies, Hiroshima City University, Japan \\ abdulwasiuraji5@gmail.com,mdhaniff@uum.edu.my; \\ msubhan@uum.edu.my;azam73jp@gmail.com \\ DOI: https://doi.org/10.32890/jis2017.13.6
}

\begin{abstract}
The state of electricity supply in Nigeria is nothing to write home about. The situation has resulted in the government adopting the privatization policy as the elixir to the affliction of inadequate power supply in the country. Thus, this paper investigated the privatization policy of the power sector and how it affects development in the rural areas of the Ijumu local government of Kogi State, Nigeria. The modernization theory was adopted in this paper. Data acquired from 120 respondents selected with the use of the three-stage sampling procedure, was analyzed with Statistical Packages for Social Sciences (SPSS/PC) Version 20. The study revealed that privatization of the power sector has not transformed into a significant improvement in electricity supply. Consequently, the study recommends that there is need for the government to ensure that the policy adopted should be of optimum form to achieve the desired results.
\end{abstract}

Keywords: Privatization policy, rural development. Ijumu, Nigeria.

JEL: M5 and O1

\section{Introduction}

A solemn duty of a nation is the provision of basic amenities to its citizens. To attain this, certain enterprises are fashioned to deliver these amenities to the people. Public enterprises stand as a sort of bridge, linking the government and its citizens owing to the opportunities it offers in terms of sufficient employment and reasonably priced services. However, the choice of privatization or commercialization does come up when the rudimentary functions of these enterprises are not accomplished due to corruption, inefficiency, mismanagement and the likes. In lieu of these problems some public enterprises were privatized, with other public enterprises that escaped its yoke commercialized so as to be rid of the observed glitches in the services provided (Claudius, 2014). 
By all standards, to privatize connotes an attempt to: avoid economic wastage; corruption as well as mismanagement of fund; promote job opportunities, increase the inflow of foreign investors, etc. (Okigbo, 1986).Thus, in the process of inaugurating the National Council on Privatization(NCP), former President Obasanjo stated thus: State enterprises writhe from problems of substandard capital structure, undue bureaucratic control or intrusion, inapt technology, starkin eptitude and maladministration, brazen corruption and crippling self-satisfaction which monopoly breeds. As a consequence of these, privatizing is for the advantage of economic salvage and benefit of life. The goal is not just to replace public monopoly with private monopoly, but, rather in the determination to be firm and inflexible in the best interest of this nation. The removal of the financial burden which these enterprises create on the public is necessitated so as to allow for the liberation of resources for the critical functions of the government (Kande cited in Erunke, 2007).

In the wake of the privatization policy, other matters arose as a consequence of some of the privatized public enterprises finding survival to be a herculean task. Examples are the Ajaokuta Steel Co. Ltd, Nigeria Paper Mills and some privatized refineries. In the view of Ayodeji (2012 cited in Aminu et al., 2014), the privatization of austerity has resulted in the death of most of the privatized public corporations. The plague of inefficiency and corruption lingers in these corporations despite being privatized and Power Holding Company of Nigeria ( $\mathrm{PHCN}$ ) is a sufficient example Nigerians can relate to presently due to the use of electricity by all. Erunke (2007) is of the view that agents of the government have practically high jacked the benevolence and ambition of public policies such as privatization, and transformed them into private initiatives to enrich themselves, their families and friends, and business associates both at home and abroad.

Another relevant issue is the public enterprises undergoing privatization in line with the nature of service being made available to the people. Public establishments like PHCN, Education, and Health centers among others, are not meant to be privatized because of the sheer importance of these public corporations to both the poor and rich members of the society. Developed nations of the world, such as Belgium, France, Ireland and Greece still control about 90 percent of the electricity market notwithstanding an agreement for full energy liberalization by the year 2007 (Majone, 2003). These nations do not discharge important sectors to the hands of private individuals being aware of the effects on the citizens.

However, the concept of privatization has remained a topic of powerful global debates in recent years. In Africa, it has lingered as highly controversial and confusing. The privatization policy in Nigeria has drawn much criticism from the academia and individuals. In Nigeria, the organized labor union has embarked on several strikes as well as issued threats of strike against the privatization of key government corporations. In 2006, the National Electric Power Authority (NEPA) was privatized and altered into the Power Holding Company of Nigeria (PHCN). This was done in order to boost the quality of electricity distribution in Nigeria and promote efficiency in the corporation. A lot of studies have been conducted 
on the power sector prior to and after privatization and more discoveries have been made. (Olori, 2005 cited in Claudius, 2014). Electricity supply in Nigeria has always been utterly inadequate and problem-ridden but gradually encountered a crisis in the late 1990s.Thus, after privatization, Rabiu (in Uduma, 2009) postulated that Nigeria now has a declining economy. "Naturally, people stockpile electricity generating plants that consume petrol directly in their houses. As a consequence of this practice, lives and properties have been lost due to fire accidents and in some instances, suffocation of inhabitants from smoke and Co2".

Rural development represents a cohesive determination of the government and the rural dwellers to significantly bolster living standards in rural areas. Rural development can arise in varying proportions ranging from health service, quality education, water supply, good roads, electricity supply and other factors that can bring value to the standard of living in rural areas. Nigeria as a nation had put forth several programs in the past to improve rural areas. It is very essential to note that electricity supply is as well needed in rural areas as in the urban centers. Therefore, there should be no discrimination in the supply of electricity to the people of the rural areas. However, the reverse is the case in Nigeria as the gap between the rural and urban areas in terms of electricity supply is critically wide. This gap according to Igboeli (in Akpomuvie 2010) has its origins in the neo-classical economic theories which assume that "development can be hastened by the concentration of investments in cities and that rural poverty will be solved by the trickle down of the reaped benefits from urban industrial growth". With the so-called growth-centered policy, the developing nations have persisted in witnessing imbalances in the living standard between the rural and urban dwellers.

The aim of this paper was to ascertain a relationship between privatization policy and rural development through an assessment of the Power Holding Company of Nigeria. Although, development in the rural areas can be measured through diverse perimeters, this paper made the power sector its center by examining how privatization in the sector can bring forth improvement in the living standard of the rural dwellers.

\section{Problem Statement}

The state of electricity supply in Nigeria is borderline disastrous. Darkness is seen more or less as the norm and the supply of electricity as a golden gift to be treasured for what little time provided. Both urban and rural areas suffer from the low supply of electricity for their domestic as well as industrial use. In addition, areas populated by people as a result of small industries like sawmills and hotels such as Ayetoro Gbede, Iyara, Iyamoye and EkinrinAdde, encounter similar fate. The state of electricity in Nigeria has become a nationwide embarrassment that has cost the country massive amounts of money as numerous investors find it problematic to settle in the nation for business. As an alternative, investors look to neighboring nations such as Togo, Ghana, and the Benin Republic to set up their businesses as a consequence of the perilous condition of electricity in Nigeria. Even some of the 
previously established ones such as Dunlop Nigeria have lost to the neighbouring countries since electricity supply is significantly better there than as it is in Nigeria. Considering the bad shape of electricity in urban centers, one can only imagine how terrible it must be in rural areas. This is not proper as most of the rural dwellers do not have sufficient funds to make use of other power sources such as generators, inverters and solar among others.

The rickety supply of electricity in rural areas has made rural developmental efforts all for naught. If pipe-borne water is made available, where is the electricity to facilitate it? If modern health care facilities are made available, electricity is required to run the medical equipment. If schools are erected with modern educational equipment made available, will they operate in blackouts? This can go on and on. Electricity supply is more or less intertwined with rural developmental efforts. The sheer presence of stable electricity is an enough motivating factor to attract businesses and individuals to migrate.

With the above, it is apparent that electricity is a crucial part of developmental efforts. Barrages of resources have been wasted due to the current state of electricity in the nation and crucial attention is required to curtail further losses. It is somewhat amusing that countries like Togo, the Benin Republic and some parts of Cameroun sourced their electricity in Nigeria while these countries enjoy electricity supply, Nigeria does not. In terms of accessibility, a large proportion of rural areas seem to be left out in the map of areas to be supplied electricity while the lucky ones that are given electricity experience nothing short of an epileptic supply. Electricity seems more or less to the rural dwellers like fire was to the caveman before its discovery; a mystery. Rabiu (in Uduma 2009) claims that some ruralites he interviewed posited that "they have lived in the blackouts unendingly and any time there is power supply, it is always erratic and the current is either low or high to cause damages to devices".

This above problem is not only found in rural areas, it is as also prominent in urban centers, and a lot of properties have been damaged due to the erratic electricity supply. In other circumstances, this could lead to the destruction of an entire building. Despite this, the Power Holding Company of Nigeria does not feel mortified in over-charging its consumers on the electricity they cannot enjoy. This issue of over-charging, commonly known as "Crazy Bill" is popular in the urban and rural centers but it is at its peak in the rural communities due to the level of illiteracy among the individuals. Some villages like Odokoro Gbede, Araromi Gbede, Okoro Gbede, Ogidi and so on, in the Ijumu local government of Kogi State do not even make use of metres; rather an estimated charge is given to each family.

\section{Objectives}

The following are the objectives of this study:

1. To examine the relationship between privatization policy in the power sector and improvement in power supply. 
2. To examine the relationship between privatization policy in the power sector and the attraction of new business endeavors and immigrants.

\section{Literature Review}

\section{Origin of Privatization}

Following independence, it has become glaring to most African nations that neither the state enterprises they dealt with nor the little, dispersed private sectors in control of alien investors could yield goods and services that would gratify the desires of the newly independent people (Omoleke 2011). It seems the 'inherited' enterprises are far too difficult for the Nigerian government to control since they are not the initiators of those enterprises. Anyebe (2002 cited in Aminu et al., 2014) placed the figure of the public enterprises in 1983 to be more than 110 enterprises ranging from transport, aviation, oil, shipping, and vehicle assembly and manufacturing companies. Derailing from the duty of sustaining the acquired public enterprises, Nigeria still went ahead to obtain more from foreigners through its indigenization policy of 1972. This resulted in the high number of public enterprises. Ogundipe (1986) revealed that from 1975 to1985 state investment and subsidies in government-owned enterprises were more than 23 billion naira.

Iheme (1997) observed that privatization connotes the effective management of the economy via the participation and dominance of market forces in a bid to ensure honesty via healthy competition. Raji et al. (2016) averred that the term involves reallocation of properties from the state to the private sector. They noted that the concept implies disengagement of the state from businesses that can be best managed by private individuals. The previous nations that strongly went against the policy have incorporated the policy as a technique of enhancing their socio-economic performance. These countries include those in the eastern bloc such as Romania, Russia and Czechoslovakia among others. It is on record that over eight thousand five hundred $(8,500)$ government enterprises in more than eighty $(80)$ nations have been privatized in the past 12 years' (Igbuzor, 2003).Privatization in Nigeria can be linked historically to the administration of Ibrahim Badamosi Babangida through the Structural Adjustment Program (SAP). The administration propagated Section 14, Decree No 25 in 1988 which aided the privatization policy for selected public enterprises in the nation. During the period, certain public enterprises which were yet to be privatized were commercialized as a result of the worldwide economic depression in the 1980.

\section{An Overview of the Privatization Policy of the Power Sector in Nigeria}

Electricity supply is being acknowledged over the years to be germane to the development of any society. According to Claudius (2014), the first generating power plant was mounted in Marina in 1898. It is worthy to note here that the first generation of electricity power supply 
transpired during the colonial era and was accomplished by the colonial administration. Preceding the amalgamation of 1914, the Electric Utility Company started its operation in the country in 1929, and it was known as the Nigerian Electricity Supply Company (NESCO) with the building of a hydro-electric power station at Kurra, Jos (Uduma 2009). In 1951, the Electricity Corporation of Nigeria (ECN) was fashioned as a substitute for NESCO while the Niger Dam Authority (NDA) was established to enhance the hydropower potentiality of Nigeria. However, in 1972 ECN and NDA were fused which was later known as the National Electric Power Authority (NEPA) after the enactment of Decree No 24 of 1972 with authority to produce and sustain effective power supply to all parts of the country (Uduma 2009).

According to Aminu et al. (2014), in 1988, NEPA was partly commercialized, supported by an upward appraisal of the tariffs. This was aimed at enticing investors to the sector and the status lasted till the civilian government came to rule in 1999. The rise of the civilian administration of Olusegun Aremu Obasanjo paved the way for the full deregulation of the power sector. According to Section 1999 of the constitution of the Federal Republic of Nigeria, Section 316, NEPA was to retain the monopoly of the Electricity Utility Corporation in Nigeria. The administration at first came up with a new electricity policy known as the National Electric Power Policy (NEPP) in 2001. This policy became a forerunner of the Electric Power Reform (EPSR) Act of 2005 with most of the noteworthy elements of NEPP (2001) included in EPSR (2005) (Federal Ministry of Power and Steel, in Uduma, 2009).

In 2006, a brand new technical board, accountable to the former president Obasanjo under the chairmanship of Senator Liyel Imoke, was selected to supervise the administration of NEPA and its ensuing privatization. On $1^{\text {st }}$ July 2006, NEPA was changed to PHCN in consonance with the on-going government Power Sector Reform Program (Claudius 2014). The PHCN, as a company, consisted of 18 sub-companies; one transmission company (TRANCO), six generating companies (GENCO) and 11distributing companies (DISCO). Presently, the government owns $100 \%$ of the transmission corporation, while its holdings on the generating companies is $20 \%$ (with $80 \%$ of equity sold to private investors) and in the case of the distribution companies, eleven of them have been sold. The government only traded $60 \%$ and still holds $40 \%$ (Claudius 2014).

\section{Rural Development}

Ogidefa (2010) posited that rural development involves the creation and expanding of prospects for (rural) dwellers to appreciate the full potential via education and share in the decision and action which touch their lives. To Ogidefa, there is rural development when opportunities are present for ruralites to realize their potential. It is stimulating to note that rural development is a multifaceted concept which different scholars explain from varying angles. However, one thing which is common is the trait of the objective of rural development, which is to uplift rural areas from the current level to a better level. At some 
time, rural development may target education, agriculture and infrastructural facilities, while at some other time it may be geared towards political participation or economic development. At this juncture, rural development can simply be seen as a concerted effort directed at bringing both qualitative and quantitative development to the living standard of the rural dwellers at a particular period of time. According to Sunday (in Ise, 2014), power is needed for essential services like health care, education, telecommunications and pipeborne water. Programmes like Universal Basic Education, poverty eradication and other empowerment programmes require electricity. Lack of stable power supply does not only result in the local inhabitants being backward, but has also affected their economic fortune.

\section{Theoretical Framework}

According to the Modernization theory, the less developed nations can advance their standard of living only via a period of extreme economic growth and supplementary changes in people's belief, attitude towards work and values (Robert, 2004). Modernization theorists contend that under-developed nations lack cultural traits that are well-matched with development and that only developed countries can back these countries to move towards development.

Levy $(1966,1967)$ differentiates 'relatively modernized' and 'relatively non-modernized' societies based on the extent to which tools as well as inanimate sources of power are exploited. In the view of others, the concept pinpoints an open-ended form of social change, as when historian Schwartz (1972) sources from the work of Max Weber to describe modernization in terms of the growth of man's rational dominance over his social and physical environment (see also Hall, 1965, and Rustow, 1967). In addition, another view in the conceptualization of modernization sees it not as a form of change but as a response to change, such as in the conceptualization of Halpern (1966) which posits the capability of institutions to acclimatize to or control speedy and continuous change. Eisenstadt (1966) claims that modernization is dominated by two features; structural differentiation and the capability of institutions to adapt to changing demands and problems.

Based on this, as a response to the problems faced by the government in maintaining ample electricity supply, privatization of the power sector is seen as a veritable solution to the problem. In essence, privatization of the power sector should lead to competition in the market. This should result in what Adam Smith called "the invisible hand". This lack of hegemony should ensure that electricity is made available to the populace at the optimum price possible. Privatization is a concept closely linked to capitalism. The modernization theory postulates that for underdeveloped nations to make progress in their march towards development, institutions have to be modelled after successful capitalist nations. Therefore, as privatization in the power sector is in use in a country such as USA, underdeveloped nations therefore, have to strive to do this as well in order to achieve development. 


\section{Methodology}

The research work was carried out in the Ijumu local government of Kogi State. The survey method was used to gather data for the study. The three-stage sampling procedure was used to select 120 respondents for the survey. Firstly, cluster sampling techniques were adopted to divide the local government into three districts, namely Gbede, Ijumu Oke and Ijumu Arin. Secondly, simple random sampling was used to select two villages from each district. Lastly, purposive sampling was employed in selecting respondents that have been residing before and after the privatization of PHCN in those villages, especially those who have knowledge of the state of events in their villages regarding electricity.

The questionnaire administered to elicit information from the respondents contained close-ended questions only. The questionnaire had three (3) sections. Section A contained questions on the demographic and socio-economic background of the respondents. These included questions on age, sex, educational qualification, occupation and income. Section B contained questions on how the respondents have been affected by the erratic power supply, while Section C contained questions on the benefits rural development would bring to the ruralites, and the country as a whole.

Statistical Packages for Social Sciences (SPSS/PC) Version 20 was used to analyze the data gathered for the study. The questionnaires that were returned were edited and coded for easy analysis with the SPSS/PC. The statistical methods used in the analysis included percentages, mode, cross-tabulation, chi-square and contingency coefficient.

\section{Results}

Socio-demographic Factors of the Respondents

\begin{tabular}{lcc}
\hline Socio-demographic characteristics & Frequency & Percentage (\%) \\
\hline Age & 30 & 25 \\
Below 25 years & 53 & 44 \\
26-35 & 19 & 16 \\
36-45 & 18 & 15 \\
Above 46 & 60 & 50 \\
Gender & 60 & 50 \\
Male & & \\
Female & & 30 \\
\hline Marital Status & 36 & 67 \\
Single & 80 & 3 \\
Married & 4 & \\
Widowed & & (continued) \\
\hline
\end{tabular}


Privatization Policy and Rural Development: An Assessment of Power Holding Company of Nigeria in Ijumu Local Government of Kogi State

\begin{tabular}{lcc}
\hline Socio-demographic characteristics & Frequency & Percentage (\%) \\
\hline & & \\
Occupation & 7 & 5 \\
Employed & 99 & 12 \\
Self-employed & 14 & 100 \\
Student & 120 & \\
\hline Total & & \\
\hline
\end{tabular}

Source. Researcher's Fieldwork (2017).

\section{Hypothesis One}

$\mathrm{H}_{\mathrm{o}}=$ There is no serious correlation between the privatization of the power sector and improvement in electricity supply.

$\mathrm{H} 1$ =There is a serious correlation between the privatization of the power sector and improvement in electricity supply.

\begin{tabular}{lccc}
\hline \multirow{2}{*}{ Electricity supply in a day } & \multicolumn{2}{c}{ Improvement in electricity supply } & \multirow{2}{*}{ Total } \\
\cline { 2 - 3 } & Yes & No \\
\hline & & & \\
Below 5 hours & 9 & 86 & 95 \\
$\mathbf{5 - 1 0}$ hours & 1 & 11 & 12 \\
$\mathbf{1 1}$ hours and above & 0 & 13 & 13 \\
& & & 120 \\
\hline Total & 10 & 110 & \\
\hline
\end{tabular}

Researcher's field work (2017).

$\chi^{2} \mathrm{c}-0.055, \chi^{2} \mathrm{t}-5.991$, DF-2Alpha level-0.05

Decision Rule:

Since $\chi^{2} \mathbf{c}$ is lesser than $\chi^{2} \mathbf{t}$, the alternate hypothesis is rejected and the null is accepted.

Hypothesis Two

$\mathrm{H}_{\mathrm{o}}=$ There is no serious correlation between privatization and the attraction of new business endeavors and people.

$\mathrm{H} 1=$ There is a serious correlation between privatization and the attraction of new business endeavors and people. 


\begin{tabular}{|c|c|c|c|}
\hline \multirow{2}{*}{$\begin{array}{l}\text { Privatization of PHCN has led to improvement in } \\
\text { electricity supply }\end{array}$} & \multicolumn{2}{|c|}{$\begin{array}{l}\text { Attraction of businesses and } \\
\text { people }\end{array}$} & \multirow{2}{*}{ Total } \\
\hline & Yes & No & \\
\hline Yes & 5 & 7 & 12 \\
\hline No & 20 & 75 & 95 \\
\hline I don't know & 3 & 10 & 13 \\
\hline Total & 42 & 119 & 120 \\
\hline
\end{tabular}

Researcher's field work (2017).

$\chi^{2} \mathrm{c}-0.159, \chi^{2} \mathrm{t}-5.991, \mathrm{DF}-2$ Alpha level-0.05

Decision Rule:

Since $\chi^{2} \mathbf{c}$ is lesser than $\chi^{2} \mathbf{t}$, the alternate hypothesis is rejected and the null is accepted.

Discussion of Findings

From the collected data, it was discovered that $30(25 \%)$ of the respondents were below 25 years of age, $53(44 \%)$ were in the age range of 26-35, $19(16 \%)$ in the range of 36-45 and $18(15 \%)$ above 46 years. It was discovered that $60(50 \%)$ of the respondents were males with the remaining $60(50 \%)$ being females. Also, the study revealed that $36(30 \%)$ of the respondents were single, $80(67 \%)$ were married with the remaining $4(3 \%)$ being widowed.

\section{Limitations of the Study}

While the findings of this paper are believed to have satisfactorily answered the objectives raised, there are some limitations that still need to be recognized. With the use of questionnaires, there are natural limitations like response bias, the likely insincerity on the part of the respondents which can hinder the findings, though, proper steps were taken while administering the questionnaires in order to reduce the limitations to the barest minimum. Furthemore, there is the limitation of generalizing the findings of the study to other local government areas in Kogi State. However, the findings of the study may be useful in assessing the privatization of the Power Holding Company of Nigeria (PHCN) especially in other local governments that, by nature, share the same characteristics with Ijumu LGA of Kogi State.

\section{Conclusion and Recommendations}

From the analyzed data, it can be inferred that the privatization of the power sector has not transformed into a significant improvement in electricity supply. Thus, it has led to a series 
of chain reactions which can be summed up as the lack of social amenities. If running water is made available, there is no electricity to pump it. If modern educational facilities such as projectors, e-library, etc. are made available, there is no electricity to facilitate the usage. According to Raji et al. (2017), education has a regulatory sway over the development of rural areas and communities. The lack of sufficient electricity to make modern educational facilities useful therefore, impinges on the nation's developmental status.

Given the findings of this study, the following recommendations are proffered towards the relationship between privatization and rural development. The recommendations are as follows:

1. The government should ensure that it adopts the optimum form of privatization to the power sector in order to achieve the desired result.

2. Rural developmental plans such as those addressing education and healthcare facilities should go hand in hand with the improvement in electricity supply, as it is germane to the functioning of these facilities

3. The government should ensure that the interests of the people are being safeguarded even after a sector is privatized.

4. There should be proper funding of the power sector in order to significantly improve the capacity of electricity in the country.

5. There should be competition among investors in the sector as this will serve to reduce the tendency of private monopoly.

\section{References}

Akpomuvie, O.B. (2010), Delta State University (Abraka, Nigeria) Journal of Alternative Perspectives in the Social Sciences Vol 2, No 1, 88-111.

Aminu,Isa and Pterside, Zainab, B. (2014). The impact of privatization of power sector in Nigeria: A political economy approach. Meditterian Journal of Social Science, 26, 111-118.

Claudius, A.A, (2014); Nigeria electricity industry: Issues, challenges and solution. Public Lecture Series, Vol.3, No.2, October.

Eisenstadt, S. N. (1966). Modernization: Protest and change. Englewood Cliffs, N.J.: Prentice-Hall.

Erunke, C.E. (2007). Privatization policy in the power sector: A German experience. Paper presented at Public Policy Analysis Seminar NSUK, 2007, May (Unpublished).

Igbuzor, O. (2003). Privatisation in Nigeria: Critical issues of concern to civil society. Paper presented at a Power Mapping Roundtable Discussion on the Privatisation Programme in Nigeria. Abuja, 3rd September.

Iheme, E. (1997). The Incubus: The story of public enterprises in Nigeria. The Helmsman Associates, Abuja. 
IseOlorunkanmi O. J. (2014). Issues and challenges in the privatized power sector in Nigeria, Journal of Sustainable Development Studies, 6 (1).

Levy, Marion, J. Jr. (1966). Modernization and the structure of societies. Princeton, N.J.: Princeton University Press.

Levy, Marion, J. Jr. (1967). Social patterns (structures) and problems of modernization.. In Wilbert E. Moore and Robert M. Cook (Eds.), Readings on Social Change, pp. 189208. Engle wood Cliffs, N.J.: Prentice-Hall,.

Majone, G. (2003). Deregulation, liberalization and regulatory reforms in European Union. Mexico. Paper presented at the $5^{\text {th }}$ Global Forum on Reinventing Government, Panel on Deregulated Government, Mexico $3-7$.

Ogeidefa, I. (2010). Rural development in Nigeria: Concept, approaches, challenges and prospect. SOCYBERTY.

Ogundipe, V. (1986, January 7). The inevitability of privatization. The Guardian, 7.

Okigbo, P. (1986). National development plan in Nigeria 1900-1907. Enugu: Fourth Dimension Publishers Ltd.

Omoleke, I.I. (2011). Management of electricity generation and supply in Africa: The Nigerian experience. Journal of Public Administration and Policy Research, 3(10), 266-277.

Raji et al. (2017). Nomadic education and rural development in Orelope Local Government Area of Oyo State (unpublished).

Raji, A.A., Nurhaizal Azam, A., \& Muhammed, S. (2016). Impact assessment of the privatization policy on the Nigerian economy (1999-2015): Asia Pacific Journal of Education, Arts and Sciences, 3(2), 21-26.

Robert, M. (2004). Modernization theory: Then and now.

Rustow, Dankwart, A. (1967). A world of nations; Problems of political modernization. Washington, D.C.: The Brookings Institution.

Schwartz, Benjamin, I. (1972). The limits of "Tradition versus Modernity" as categories of explanation: The case of the Chinese intellectuals. Daedalus, 101(2), 71-88.

Uduma, E. (2009). Rural development strategies and the challenges of achieving the millennium development goals in Nigeria. 